W. YE, ${ }^{1}$ S.Q. LIU, ${ }^{1}$ and Y.J. ZENG ${ }^{2}$

\title{
PECULIARITIES OF THE TAIL-WITHDRAWAL REFLEX CIRCUIT IN APLYSIA: A MODEL STUDY
}

\author{
Received January 12, 2013.
}

The circuit of the tail-withdrawal reflex in Aplysia opens up possibilities to construct model systems allowing researchers to effectively investigate simple forms of learning and memory. Using the Python interface of the NEURON software, we simulated this reflex circuit and studied various characteristics of the latter. The phenomenon of spike frequency adaptation (SFA) and the period-adding bifurcation of the minimum were found in sensory neurons, when the latter were stimulated by square-wave stimuli. In all neurons of the circuit, variation of the stimulus strength first increased and then decreased the number of spikes in a burst. In addition, with decreases in the number of stimulated sensory neurons, a subliminal firing other than that in an intact burst appeared at the outputs of interneurons and motor neuron. Moreover, the potentials produced in the motor neuron induced corresponding oscillations of the muscle fiber force, which was indicative of a procedure of excitement-contraction coupling in the tail part of Aplysia. Finally, upon alteration of the conductance of synapses between interneurons and motoneuron, the duration of long-lasting responses increased regularly, implying synaptic plasticity.

Keywords: Aplysia, tail-withdrawal reflex, spike frequency adaptation, synaptic plasticity, muscle fiber force.

\section{INTRODUCTION}

The nervous system of a marine mollusk, Aplysia (Gastropoda), is an extensively used object in the studies of reflexes, due to the relatively simple structure of this system [1]. In Aplysia, there are two important motor reflex reactions, the tail-withdrawal reflex and the gill-withdrawal reflex (note that the term "tail" is conventionally attributed to the posterior part of the mollusk's body despite the fact that the tail per se, in the strict sense of the term, exists only in Chordata). Both the above-mentioned motor phenomena are examined because data obtained help researchers to understand the general principles of functioning of the reflex neuronal networks [2]. Owing to the relatively simpler pattern of the neuronal circuit, considerable attention was focused on the tail-withdrawal reflex. In reality, the arc of this reflex includes three kinds of neurons: sensory units, interneurons, and motor

\footnotetext{
${ }^{1}$ South China University of Technology, Guangzhou, China

${ }^{2}$ Biomedical Engineering Center, Beijing University of Technology, Beijing, China

Correspondence should be addressed to: Y.J.Zeng or S.Q.Liu

(e-mail: (yjzeng@bjut.edu.cn)
}

neurons. Many studies were focused mainly on the monosynaptic connections between sensory neurons and motor neurons, which were thought to be a site of plasticity [3]. For example, Phares et al. [4] studied the contribution of synaptic depression to the monosynaptic circuit. Although these authors could simulate the properties of basic firing, the longduration (long-lasting) responses observed in the physiological experiments could not be reproduced, and the role of interneurons interposed between the sensory and motor neurons was not analyzed. White et al. [1] improved the former models by constructing a polysynaptic circuitry that included interneurons. This circuitry, consisting of monosynaptic and polysynaptic pathways, reproduced long-lasting responses and drew attention to the phenomenon of the synaptic plasticity modifying the synaptic connection. Baxter et al. [5] developed this polysynaptic model by adding synaptic depression and potentiation to modulate synaptic connection. Most of the above-mentioned researches, however, focused only on the correspondence of the spiking patterns between actual neurons and the model network. The properties of the muscle, i. e., the effector of the reflex, were not discussed in the above papers. 
Motor neurons are central elements that provide connections between the CNS and muscle fibers $[6,7]$. Due to the fundamental difficulties of experimental research, there are still lots of problems on how motor neurons or a neural network control muscle fibers to achieve certain characteristics of the activities. Consequently, much attention was focused on the computational approach to simulate the neural network and muscle fibers. Bashor [8] constructed a neural network simulating that in the cat; this network associated two antagonistic muscles to study the influences coming to the muscles from the network. Cisi and Kohn discretized the critically damped secondorder system that was further developed by Fuglevand et al. $[6,9]$. This discrete model made simulation much simpler, and its simulation/reality accuracy provided a relatively high level of successfulness in the reproduction of experimental data.

\section{METHODS}

Our tail-withdrawal reflex-simulating circuit consists of a muscle fiber model and a neural model. The neural model constructed by White et al. [5] includes four sensory neurons, two interneurons, and one motor neuron. There are two kinds of synapses between the interneurons and motoneuron: the increasedconductance and decreased-conductance synapses. The muscle fiber model constructed by Cisi and Kohn [6] receives action potentials (APs) from the motor neuron directly. These neurons, synapses, and muscle fiber form a four-layer network model (Fig. 1).

The muscle force is described by a motor unittwitch model. It is the discrete-time impulse response of a second-order critically damped system, as follows $[6,9,10]$ :

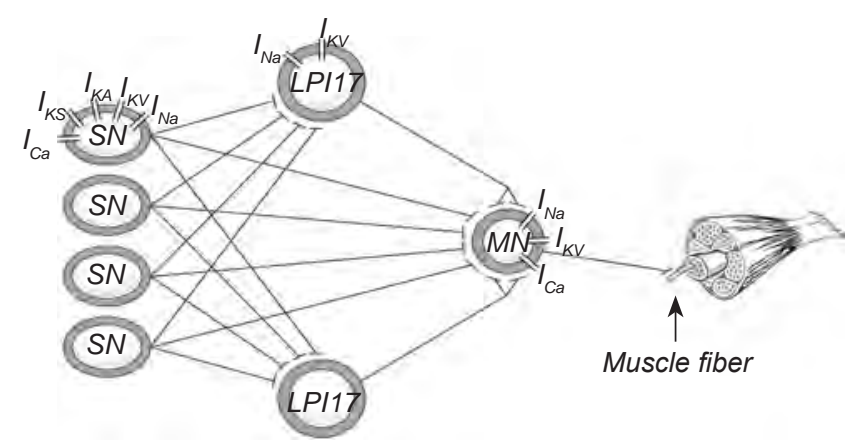

F i g. 1. Scheme of the tail-withdrawal reflex-simulating network.

Р и с. 1. Схема модельованої мережі рефлексу відсмикування „хвоста".

$$
\begin{aligned}
e(n)= & \sum_{i} \delta\left(n-n_{i}\right), \text { where } \delta(x)= \begin{cases}0 & x \neq 0 \\
1 & x=0\end{cases} \\
f(n)= & 2 \exp \left(-T / t_{\text {peak }}\right) f(n-1)-\exp \left(-2 T / t_{\text {peak }}\right) f(n-2)+ \\
& +\exp \left(1-T / t_{\text {peak }}\right) e(n-1) A_{\text {peak }} T^{2} / t_{\text {peak }}
\end{aligned}
$$

In equations (1), $n_{i}$ represents the times of motor unit activation, $A_{\text {peak }}$ is the twitch amplitude whose value is between 5 and 12.5 gram force $(\sim 0.05$ to $0.125 \mathrm{~N}), t_{\text {peak }}$ represents the twitch contraction time (between 80 and $250 \mathrm{msec}$ ), $T$ is the time step ( $\mathrm{msec}), e(n)$ represents the discrete-time spike train generated by the motor neuron, and $f(n)$ represents the muscle force.

In the circuit, every neuron is described by HodgkinHuxley-type equations,

$C_{m(i)} \frac{d V_{i}}{d t}=-I_{\text {leak }(i)}\left(V_{i}, t\right)-\sum_{k=1}^{m} I_{i o n(i k)}\left(V_{i}, t\right)-\sum_{j=1}^{n} I_{s y n(i j)}\left(V_{i}, t\right)$,

where $V_{i}$ is the membrane potential of the neuron $i, I_{\text {Leak }(i)}$ is the leakage current, $I_{\text {ion }(i k)}$ represents the current in the neuron $i$ due to the ion $k, I_{s y n(i j)}$ is the synaptic current in the cell $i$ due to the influence of the presynaptic cell $j$, and $C_{m(i)}$ is the membrane capacitance $\left(C_{m(i)}\right.$ is $0.001 \mu \mathrm{F}$ in sensory neurons and interneurons and $0.01 \mu \mathrm{F}$ in motor neuron). Each current can be modeled by $I=g(V-E)$ where $g$ is the conductance and $E$ is the reversal potential. The conductance $g_{\text {ion }(i k)}$ of an ion channel $k$ in every neuron was obtained from the following equations:

$$
\left\{\begin{array}{l}
g_{\text {ion }(i k)}=g_{\max (i k)} A_{i k}^{p} B_{i k} \\
\frac{d X_{i k}}{d t}=\frac{X_{\infty(i k)}-X_{i k}}{\tau_{A(i k)}} \\
X_{\infty(i k)}=\frac{1-B_{\min (i k)}}{1+\exp \left\{\left[V_{i}-h_{X(i k)}\right] / s_{X(i k)}\right\}}+B_{\min (i k)} \\
\tau_{X(i k)}=\frac{\tau_{X(\max )(i k)}-\tau_{X(\min )(i k)}}{\prod_{j=1}^{n \exp }\left(1+\exp \left\{\left[V_{i}-h_{\tau(i k j)}\right] / s_{\tau X(i k j)}\right\}\right)}+\tau_{X(\min )(i k)},
\end{array}\right.
$$

where $X$ represents $A$ and $B$. When there is $I_{K S}$ in the sensory neuron or $I_{K V}$ in motor neuron, $n_{\exp }=2$; for other channels, it is 1 . The conductance of the increased-conductance synapse is described by $g_{\text {syn }(i j}=$ $g_{\max (i j)} \alpha_{I C} A_{s y n(i j)}$, and the conductance of the decreasedconductance synapse is obtained from the following equation: $g_{s y n(i j)}=g_{\max (i j)} /\left(1+\alpha_{D C} A_{s y n(i j)}\right)$ where $\alpha_{D C}$ equals 7. The other synapse conductance can be described by 
Table 1. Parameters describing the membrane currents

Таблиця 1. Параметри трансмембранних струмів

\begin{tabular}{|c|c|c|c|c|c|c|c|c|c|c|c|c|c|c|c|c|}
\hline$I_{i o n}$ & $\begin{array}{c}E \\
\mathrm{mV}\end{array}$ & $\begin{array}{l}g_{\max } \\
\mu S\end{array}$ & $\begin{array}{c}h_{A} \\
\mathrm{mV}\end{array}$ & $\begin{array}{c}S_{A} \\
\mathrm{mV}\end{array}$ & $p$ & $\begin{array}{c}\tau_{A(\max )} \\
\text { msec }\end{array}$ & $\begin{array}{l}\tau_{A(\min )} \\
\mathrm{msec}\end{array}$ & $\begin{array}{l}h_{\tau A} \\
\mathrm{mV}\end{array}$ & $\begin{array}{l}S_{\tau A} \\
\mathrm{mV}\end{array}$ & $\begin{array}{l}h_{B} \\
\mathrm{mV}\end{array}$ & $\begin{array}{c}S_{B} \\
\mathrm{mV}\end{array}$ & $B_{\min }$ & $\begin{array}{c}\tau_{B(\max )} \\
\text { msec }\end{array}$ & $\begin{array}{c}\tau_{B(\min )} \\
\mathrm{msec}\end{array}$ & $\begin{array}{l}h_{\tau B} \\
\mathrm{mV}\end{array}$ & $\begin{array}{c}S_{\tau B} \\
\mathrm{mV}\end{array}$ \\
\hline \multicolumn{17}{|l|}{ SN } \\
\hline$I_{N a}$ & 70 & 10.0 & -18.2 & -8.8 & 3 & 2.0 & 0.56 & -9.0 & 7.0 & -40 & 3.2 & 0.0 & 10.0 & 2.8 & -9.0 & 7.0 \\
\hline$I_{K V}$ & -70 & 2.2 & -3.7 & -9.5 & 3 & 28. & 2.8 & 22.0 & 17.5 & -22.9 & 12.4 & 0.0 & 360.0 & 36.0 & 5.7 & 1.9 \\
\hline$I_{C a}$ & 60 & 0.01 & -20.0 & -10.8 & 3 & 50.0 & 6.0 & -20.0 & 21.8 & -20.0 & 7.9 & 0.75 & 300.0 & 225.0 & -40.1 & 33.3 \\
\hline \multirow[t]{2}{*}{$I_{K S}$} & -70 & 0.62 & 21.2 & -19.7 & 1 & 250.0 & 60.0 & -15.0 & 10.0 & & & & & & & \\
\hline & & & & & & & & -46.0 & -6.5 & & & & & & & \\
\hline \multicolumn{16}{|l|}{$\mathrm{MN}$} & \\
\hline$I_{C a}$ & 87 & 0.2 & -1.3 & -10.8 & 1 & 8.7 & 1.0 & -42.8 & 21.8 & -16.3 & 7.9 & 0.24 & 372.6 & 67.1 & -40.1 & 33.3 \\
\hline \multicolumn{16}{|c|}{ LP117 } & \\
\hline$I_{N a}$ & 70 & 8.0 & -18.1 & -8.8 & 3 & 2.0 & 0.56 & -9.0 & 7.0 & -37.0 & 3.2 & 0.0 & 10.0 & 2.8 & -9.0 & 7.0 \\
\hline$I_{K V}$ & -70 & 4.2 & -3.7 & -9.5 & 3 & 28.0 & 2.8 & 22.0 & 17.5 & -22.9 & 12.4 & 0.0 & 460.0 & 46.0 & 5.7 & 1.9 \\
\hline$I_{\text {Leak }}$ & -51.0 & 0.02 & & & & & & & & & & & & & & \\
\hline
\end{tabular}

Table 2. Parameters of synaptic connections

Таблиця 2. Параметри синаптичних зв'язків

\begin{tabular}{lcccc}
\hline Connection & $g_{\max }, \mu \mathrm{S}$ & $E_{s y n}, \mathrm{mV}$ & $\tau_{\text {syn }}, \mathrm{msec}$ \\
\hline $\mathrm{SN} \rightarrow \mathrm{MN}$ & 0.16 & 30 & 2.7 \\
$\mathrm{SN} \rightarrow \mathrm{LP} 117$ & 0.007 & 30 & 4.0 \\
$\mathrm{LP} 117 \rightarrow \mathrm{MN}$ & 0.05 & 30 & 2.0 \\
$\mathrm{LP117} \rightarrow \mathrm{MN}$ & 0.035 & -70 & 6000 \\
\hline
\end{tabular}

$g_{s y n(i j)}=g_{\max (i j)} A_{s y n(i j)}$, where $A_{s y n(i j)}$ is a synaptic activation function that can be obtained from the equation $d^{2} A_{s y n(i j)} / d t^{2}=\left(-2 \frac{d A_{s y n}(i j)}{d t} \tau_{s y n(i j)}-A_{s y n(i j)}+X(t)\right) / \tau_{s y n(i j)}^{2}$

- All parameters in the equations are listed in

Tables 1 and 2.

The network was simulated in the Python interface of NEURON [11]. All charts were plotted using the Python library Matplotlib.

\section{RESULTS}

Square-Wave Stimulus Makes Sensory Neurons Reveal Two Characteristics. In the tail-withdrawal reflex, a sensory neuron is the site that receives external stimuli, whose nature plays an important role in modifying the circuit output. To reveal the properties of the sensory neuron, simulations were performed by applying square-wave stimuli. As a result, the sensory neuron produced burst discharges that displayed some interesting characteristics. First, the frequency of action potentials (APs) declined, a phenomenon known as spike frequency adaptation, SFA (Fig. 2E). Second, an increment in the stimulus strength caused the minimum of the AP number to change regularly (Fig. 2F).

From Fig. 2 A and B, we can see that series of bursts were induced by square-wave stimuli, and the distance between two APs gradually increased. Figure 2E shows the frequency of spikes fired by the modeled sensory neuron depending on the 

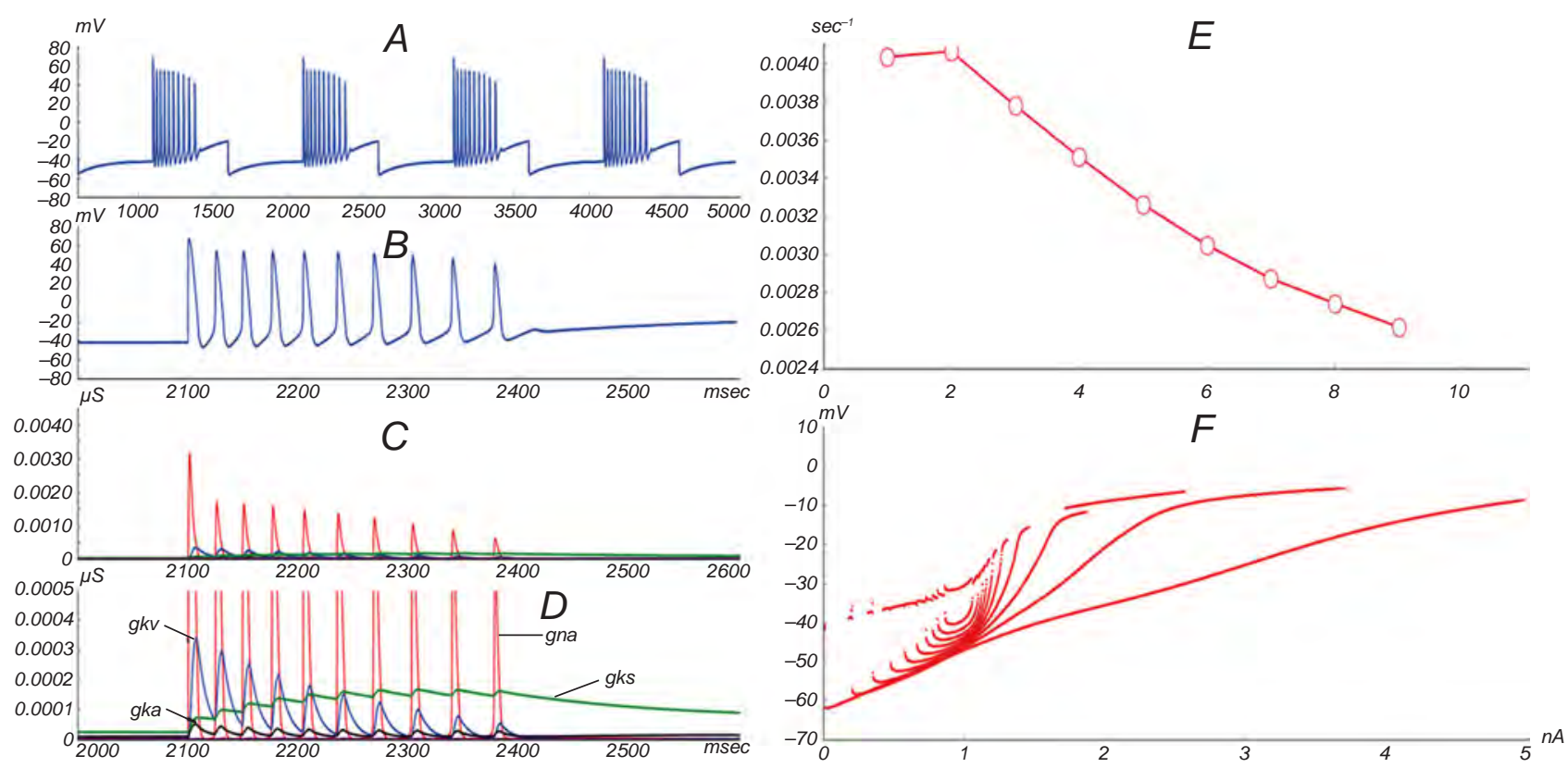

F i g. 2. Responses of the sensory neuron to stimulation. A) Series of burst discharges evoked by square-wave stimuli; B) enlargement of one burst shown in A. C) Variation of the conductance in each ion channel; D) enlargement of C. E) Instantaneous frequency of spikes (sec ${ }^{-1}$ ) related to their ordinal number. F) Minimum of the potential $(\mathrm{mV})$ varying depending on the stimulus strength (nA).

Р и с. 2. Відповіді сенсорного нейрона на стимуляцію.

ordinal on the interval between two APs. As the ordinal increases, the frequency of firing shows a corresponding reduction (i.e., SFA). The formation of SFA was mainly determined by the properties of the potassium channels. With time increase, an inactive state of the potassium channels is prolonged gradually (Fig. 2 C, D). As a result, the frequency decreases correspondingly.

Figure $2 \mathrm{~F}$ shows that the minimum of the AP number varies with increase in the stimulus strength. Initially, the minimum exhibits the period-adding bifurcation. When the stimulus strength exceeds $1.08 \mathrm{nA}$, an inverse motion could be observed.

Effect of the Stimulus Strength on the Circuit Firing Pattern. To study how the stimulus strength influences the circuit, we applied different stimuli to the sensory neuron. With increase in stimulus, the network output changes regularly, and the three kinds of neurons manifest synchronized firing (Fig. $3 \mathrm{~A}-\mathrm{H}$ ). When the stimulus strength was $0.1 \mathrm{nA}$, the sensory neuron, interneuron, and motor neuron all fired a single AP (Fig. 3 A). After cessation of the stimulus, the motor neuron became resting for $1500 \mathrm{msec}$ and then generated a long-lasting response for $4500 \mathrm{msec}$. As the stimulus strength increased, the three kinds of neurons all fired series of bursts, and the number of spikes in the bursts increased until the stimulus strength reached $1.1 \mathrm{nA}$ (Fig. $3 \mathrm{I}$ ). When the stimulus strength exceeded this value, its increment began to cause decreases in the number of spikes in the bursts (Fig. 3 I). However, independently of the stimuli strength, a long-duration response was still generated after cessation of stimulation.

In this procedure, the sensory neuron, interneuron, and motor neuron fired synchronously and generated the same number of APs when the stimulation strength was below $1.25 \mathrm{nA}$.

The Number of Stimulated Sensory Neurons Affects the Circuit Output. In our simulated network, the first layer of the circuit consists of four sensory neurons. The same stimulus was applied to different numbers of sensory neurons in order to detect the role of this parameter. The responses of such simulations are shown in Fig. 4.

When only one sensory neuron was stimulated, the potential produced by this sensory neuron did not lead to intense bursts in both interneurons and motor neuron but made them generate single spikes and subliminal firing alternately (Fig. 4A). As the number of stimulated sensory neurons increased, subliminal firing in a burst of interneurons decreased gradually, and suprathreshold firing increased correspondingly. 

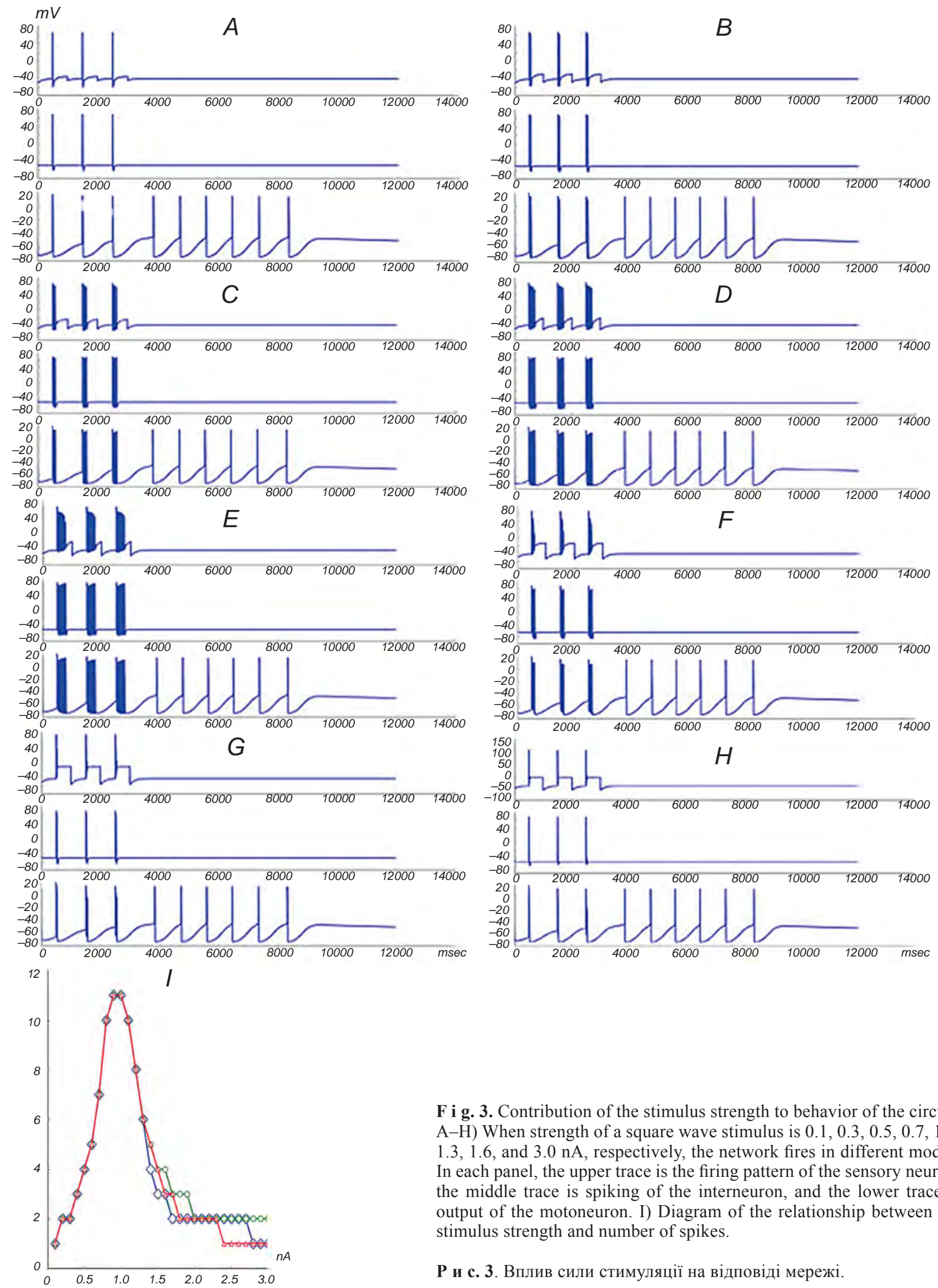

F i g. 3. Contribution of the stimulus strength to behavior of the circuit. $\mathrm{A}-\mathrm{H}$ ) When strength of a square wave stimulus is $0.1,0.3,0.5,0.7,1.0$, $1.3,1.6$, and $3.0 \mathrm{nA}$, respectively, the network fires in different modes. In each panel, the upper trace is the firing pattern of the sensory neuron, the middle trace is spiking of the interneuron, and the lower trace is output of the motoneuron. I) Diagram of the relationship between the stimulus strength and number of spikes.

Р и с. 3. Вплив сили стимуляції на відповіді мережі. 


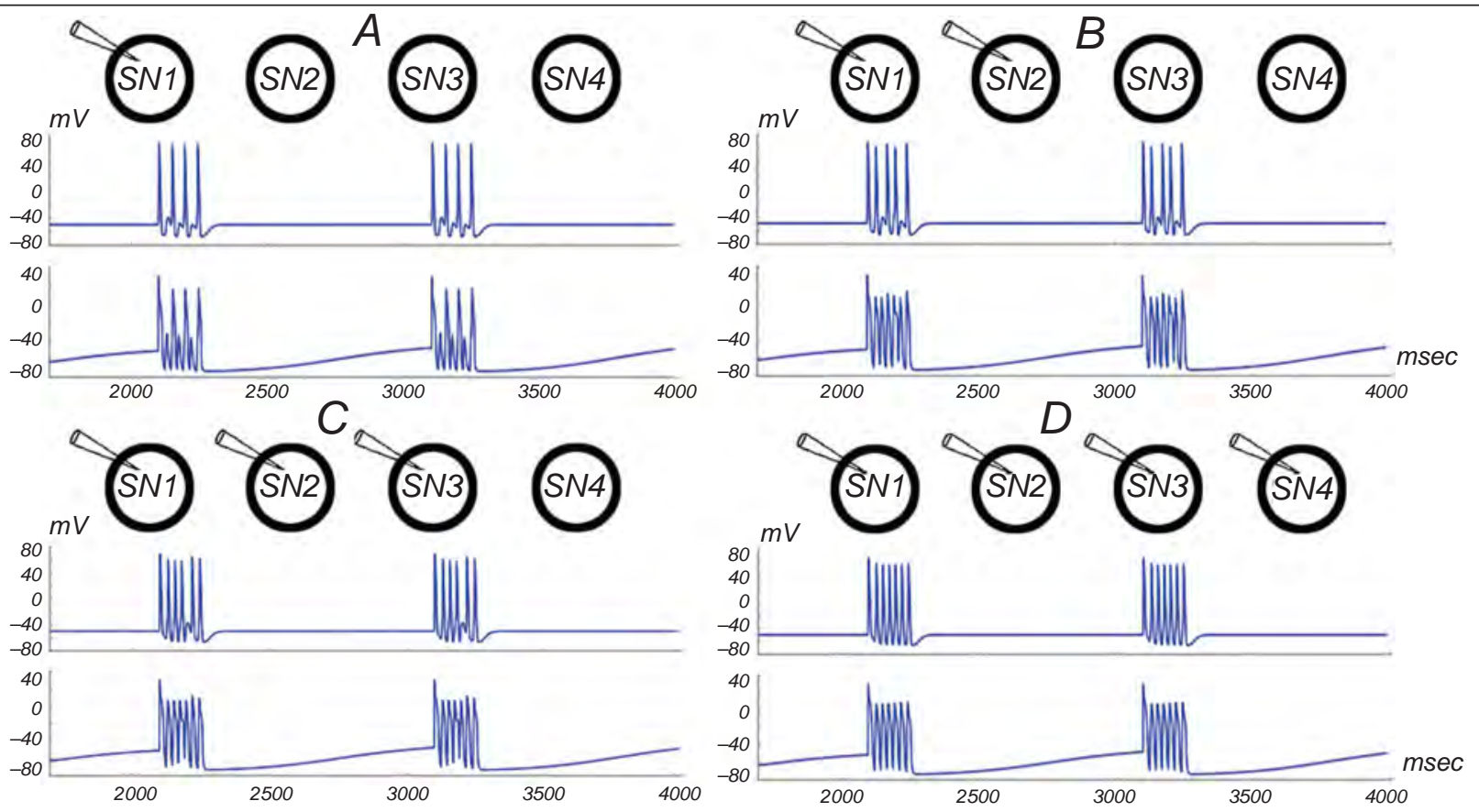

F i g. 4. Responses of the network model to stimulation of different numbers of sensory neurons. A-D) Numbers of stimulated sensory neurons were $1,2,3$, and 4 , respectively. In each panel, the upper traces are the number of stimulated sensory neurons, the middle traces illustrate the firing patterns of interneurons, and the lower traces are responses of the motor neuron.

Р и с. 4. Відповіді мережі на стимуляцію різної кількості сенсорних нейронів.
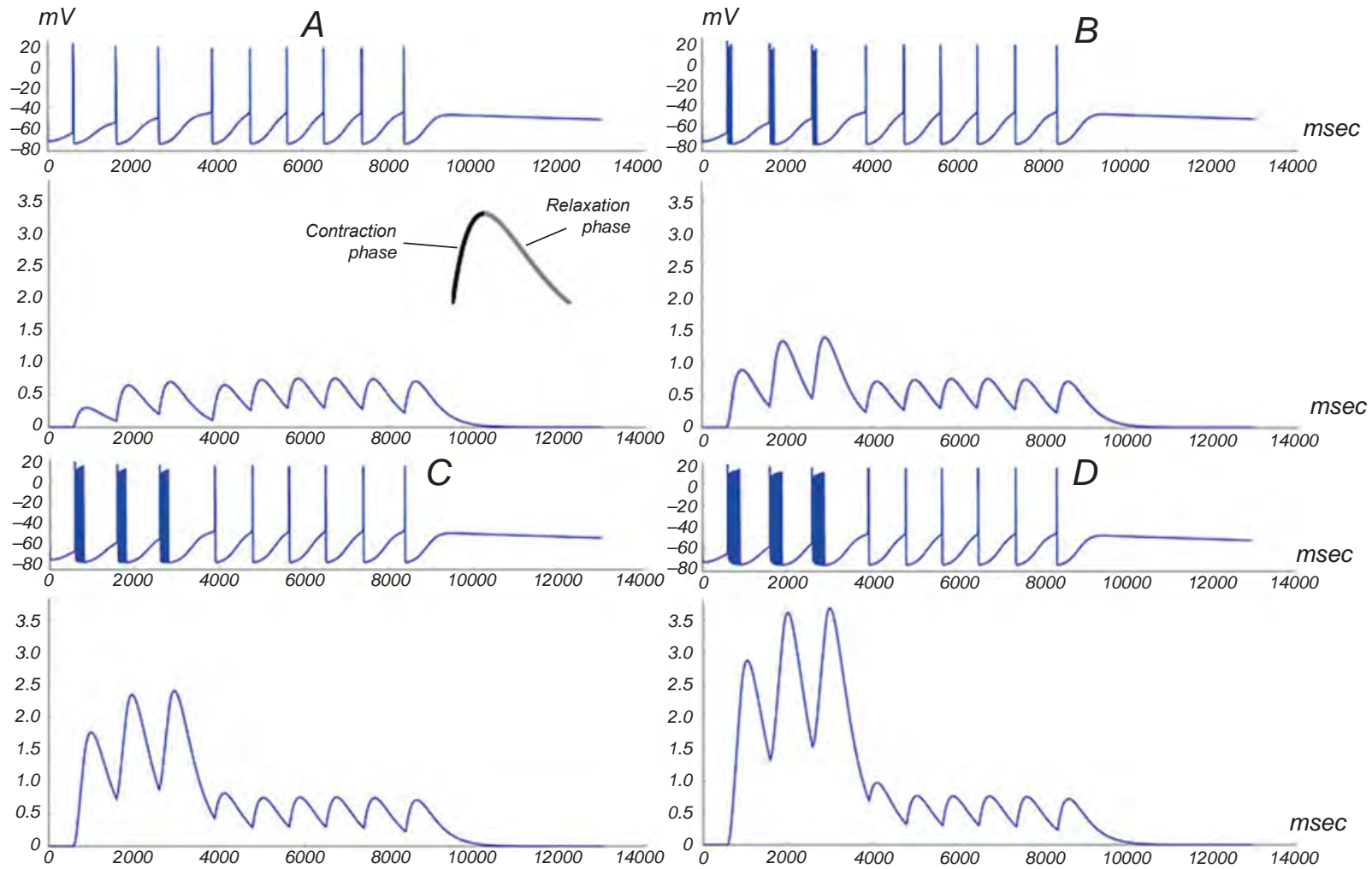

F i g. 5. Muscle fiber force responses (gram force) to changes in the membrane potential of the motor neuron. A-D) Outputs of the motor neuron and muscle fiber when the stimulus strength was $0.1,0.4,0.7$, and $1.0 \mathrm{nA}$, respectively. The upper traces are firing patterns of the motor neuron, while lower ones are responses of the muscle fiber.

Р и с. 5. Силові відповіді м’язового волокна (грам сили) на зміни мембранного потенціалу в моторному нейроні. 
Although there was no subliminal firing in the motor neuron, the amplitudes of some APs were still relatively low (Fig. 4B-C). While all sensory neurons were stimulated, subliminal firing was not observed, and series of intact bursts were produced in the interneurons and motor neuron. If the number of stimulated sensory neurons was less than three, the bursts produced in the interneuron and motor neuron were incomplete. This seems to be a factor related significantly to signal encoding in the tail-withdrawal reflex.

The Tail-Withdrawal Network Controls the Muscle Fiber Force. In order to find out how motor neurons control the muscle force, we linked our muscle fiber model to the tail-withdrawal reflex neural model. In this model, the electrical signal produced by the neural network controls the physical force developed by the muscle. Because sensory neurons, interneurons, and motor neuron fire synchronously, Fig.5 depicts the responses of the motor neuron and muscle fiber only.

As might be expected, each AP produced in the motor neuron led to oscillation of the muscle fiber force. The depolarizing potential in the motor neuron induced the muscle fiber force to increase rapidly. Moreover, the burst that contains several subsequent APs produced a greater muscle force. As we can see in Fig. 5, a single AP led to the maximal muscle fiber force of 0.72 gram force, while bursts containing 3,6 , and 11 subsequent spikes made the maximum of the muscle force reach $1.39,2.39$, and 3.68 gram force, respectively. However, when the motor neuron entered into the phase of hyperpolarization and afterhyperpolarization, the muscle fiber force began to decrease. The minimum point in every oscillation was not zero but still exceeded this value. When the motor neuron was depolarized again, the muscle fiber force assumed higher values once more. In about $9000 \mathrm{msec}$, the motoneuron became resting and did not fire anymore, and the muscle fiber force decreased to zero gradually. These results indicate that the muscle fiber force depends on the membrane potential in the motoneuron, while the potential in this neuron is in the phase of depolarization and hyperpolarization. Oscillations of the muscle fiber force are related to the excitation-contraction coupling in the muscle. As the subgraph in Fig. 5A shows, the increasing change in the muscle fiber force could lead to the contraction of the entire muscle. On the contrary, the relaxation phase in the muscle fiber is the result of the muscle fiber force decreasing [12].

Synaptic Plasticity in the Tail-Withdrawal
Reflex Circuit Model. Synaptic plasticity is an important mechanism for regulation of reflexes, learning and memory. To understand how activation of synaptic connections influences the output of the network model, we used a series of simulation tests for modulating the parameters in the synapse (Fig. 6).

The conductance of the decreasedconductance synapse is given by the equation $g_{\text {syn(iij) }}=g_{\max (i j)} /\left(1+\alpha_{D C} A_{s y n(i j)}\right)$. A increment in $\alpha_{D C}$ caused the duration of the long-lasting response of the motor neuron to rise regularly, which caused the conductance to decrease correspondingly at the same time (Fig. 6D). When $\alpha_{D C}$ was 8 , the duration of the longlasting response was $7264.9 \mathrm{msec}$, and this response caused the muscle fiber force to vary correspondingly (Fig. 6A). By increasing $\alpha_{D C}$ to 100 , the duration of the long-lasting response showed an obvious increment, increasing to $28,911.8 \mathrm{msec}$. When $\alpha_{D C}$ reached 1000 , the duration of the long-lasting response reached $44,914.4 \mathrm{msec}$ (Fig. 6C). In these procedures, the muscle fiber force oscillated with variations of the potential in the motor neuron and became zero, while the motor neuron turned into resting. Figure 6D shows a positive correlation between $\alpha_{D C}$ and the duration of the long-lasting response. When $\alpha_{D C}$ was less than 300 , the duration of such response rose rapidly. After that, the rate of increment changes entered a plateau period, and this process became relatively slow. When $\alpha_{D C}$ was greater than 5000, the long-lasting response approached a stable state. Variations of the synaptic conductance induced regular outputs in both motor neuron and muscle fiber, which may imply that there is some synaptic plasticity in the synapse between the interneuron and motor neuron.

\section{DISCUSSION}

The SFA phenomenon is a frequently observed feature of sensory neurons [13, 14]. It plays an important role in the tuning of sensory responses to specific features, which is considered a significant modulatory mechanism. This feature emphasizes the fact that sensory neurons in the tail-withdrawal reflex are involved in the regulation of the firing pattern of the entire circuit and transmission of specific electrical signals. Another feature of the sensory neuron is that the minimum of the AP number changes regularly. With increments in the stimulus strength, the minimum of the AP number shows pattern looking like a period- 


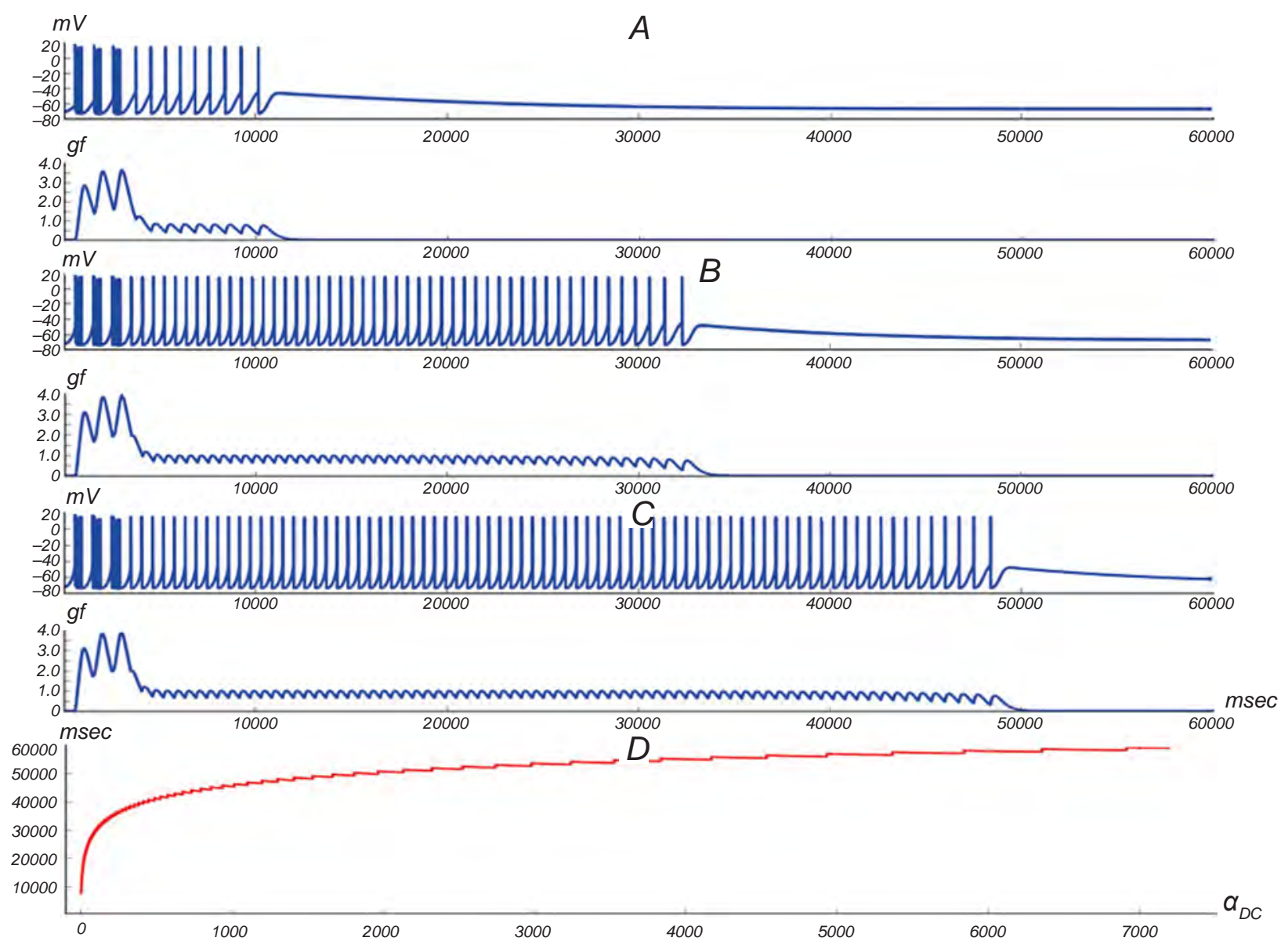

F i g. 6. Synaptic plasticity in the network model. A-C) Outputs of the motor neuron in the network model and muscle fiber model when $\alpha_{D C}$ is 8,100 , and 1000, respectively. In each panel, the upper trace is the response of the motor neuron, and the lower one is the force (gram force, gf) developed by the muscle fiber. D) Diagram of the relationship between $\alpha_{D C}$ and duration of long-lasting response after cessation of stimulation.

Р и с. 6. Синаптична пластичність у моделі мережі.

adding bifurcation. It is a mathematical characteristic that reveals a variation of the firing patterns.

Initially, the strength of stimulation correlated positively with the number of spikes at the output of the network model. When the stimulating strength exceeded $1.1 \mathrm{nA}$, the correlation between the stimulus intensity and the number of APs acquired a negative sign. This regularity may be relevant to the fatigue phenomenon, which is frequently manifested in motor reflex activity [15]. Fatigue can induce a suppression of the response when the stimulus strength exceeds a certain threshold. Thus, changes in the number of APs in the model network may be connected with the fatigue-related decrease in the magnitude of the tailwithdrawal reflex.

The data obtained using our model network agree in general with the statement that not only the mean firing rate but also the number of sensory neurons involved affect the information encoding in the tailwithdrawal reflex $[16,17]$.

Muscles of the "tail" are the effector of the tailwithdrawal reflex in Aplysia. The muscle force induced by the stimulus makes the tail perform the corresponding movements. Our results show that a positive correlation exists between the muscle fiber force and characteristics of AP bursts generated by the network. Increases in the number of spikes in a burst provide a summation effect that increases the muscle fiber force. While APs generated by the motor neuron are coming to the muscle fiber, the muscle fiber force increases correspondingly. This increment leads to more intense contraction of the muscle fiber. Then, when the motor neuron is after-hyperpolarized, this induces relaxation of the muscle fiber. Such fiber 
does not relax entirely but still maintains a certain degree of muscle contraction force. These effects provide persistent withdrawal of the tail. When the motor neuron turns into the resting state, the motor fiber relaxes entirely. However, our model allowed us to stimulate only one motor unit, while the real tailwithdrawal reflex circuit in Aplysia includes a number of motor units. More complete simulation is needed to combine a comparable number of motor units for studying how the muscle force varies.

In many studies, it was reported that synapses between interneurons and motor neurons of Aplysia is a key site of plasticity $[1,2,4,5]$. The relationship between $\alpha_{D C}$ and the duration of the long-lasting responses indicates that the plasticity phenomenon in synapses between interneurons and motor neuron in the tail-withdrawal reflex network is manifested rather clearly. Although the mechanisms of many aspects of synaptic plasticity are unknown, some assumptions with respect to this plasticity can be made according to our results. Long-lasting responses of the motor neuron can provide sustained contraction of the tail muscles [18]. Changes in the characteristics of activity generated by units of the network can modulate sustained contraction of muscle fiber of the "tail." It appears that Aplysia has a possibility to alter the duration of muscle contractions due to changes in the conductance of synapses between neurons forming the respective network.

The authors, W. Ye, S.Q. Liu, and Y.J. Zeng, confirm that they have no conflict of interest.

\section{В. Йє ${ }^{1}, Ш$. Лью}

\section{ОСОБЛИВОСТІ МЕРЕЖІ РЕФЛЕКСУ ВІДСМИКУВАННЯ} „ХВОСТА” В АПЛІЗІЇ (МОДЕЛЬНЕ ДОСЛІДЖЕННЯ)

\footnotetext{
${ }^{1}$ Південнокитайський технологічний університет, Гуанчжоу (Китай).

${ }^{2}$ Центр біологічної інженерії Пекінського технологічного університету (Китай).

P е 3 ю м е
}

Організація нервової мережі відсмикування „хвоста” в аплізії дозволяє побудувати модельну систему, за допомогою якої можна ефективно досліджувати прості форми навчання та пам'яті. Використовуючи інтерфейс Python та програмний засіб NEURON, ми змоделювали даний рефлекс та дослідили декілька властивостей модельної мережі. Феноме- ни адаптації частоти розряду (SFA) та біфуркації з доданням періоду при мінімумі частоти спостерігалися в сенсорних нейронах в умовах стимуляції прямокутними стимулами. В усіх нейронах мережі зміни сили стимуляції призводили спочатку до збільшення числа піків у пачках, а потім до його зменшення. Окрім того, при зменшенні кількості стимульованих сенсорних нейронів на виходах інтернейронів та моторного нейрона 3'являлася підпорогова кайма, що відрізнялася від такої в інтактних пачок. Більш того, потенціали, продуковані моторним нейроном, індукували відповідні осциляції сили, розвинутої м'язовим волокном, що свідчило про сполучення процесів збудження/скорочення у хвостовій частині аплізії. Нарешті, при змінах провідності синапсів між інтернейронами та мотонейронами тривалість „довгих” імпульсних відповідей закономірно збільшувалася, що вказувало на прояви синаптичної пластичності.

\section{REFERENCES}

1. D. A. Baxter and J. H. Byrne, "Short-term plasticity in a computational model of the tail-withdrawal circuit in Aplysia," Neurocomputing, 70, 1993-1999 (2006).

2. L. J. Cleary, J. H. Byrne, and W. N. Frost, "Role of interneurons in defensive withdrawal reflexes in Aplysia," Learn. Mem., 2, 133-151 (1995).

3. J. H. Byrne, "Cellular analysis of associative learning," Physiol. Rev., 67, 329-439 (1987).

4. G. A. Phares, E. G. Antzoulatos, D. A. Baxter, and J. H. Byrne, "Burst-induced synaptic depression and its modulation contribute to information transfer at Aplysia sensorimotor synapses: Empirical and computational analyses," J. Neurosci., 23. No. 23, 8392-8401 (2003).

5. J. A. White, I. Ziv, L. J. Cleary, et al., "The role of interneurons in controlling the tail-withdrawal reflex in Aplysia: A network model," J. Neurophysiol., 70, 1777-1786 (1993).

6. R. R. Cisi and A. F. Kohn, "Simulation system of spinal cord motor nuclei and associated nerves and muscles, in a Webbased architecture," J. Comput. Neurosci., 25. No. 3, 520-542 (2008).

7. M. F. Vieira and A. F. Kohn, "Compartmental models of mammalian motoneurons of types S, FR and FF and their computer simulation," Comput. Biol. Med., 37. No. 6, 842-860 (2007).

8. D. P. Bashor, "A large-scale model of some spinal reflex circuits," Biol. Cybern., 78, 147-157 (1998).

9. A. J. Fuglevand, D. Winter, and A. E. Patla, "Models of recruitment and rate coding organization in motor-unit pools." J. Neurophysiol., 70, 2470-2488 (1993).

10. L. A. Elias, V. M. Chaud, and A. F. Kohn, "Models of passive and active dendrite motoneuron pools and their differences in muscle force control," J. Comput. Neurosci., 33. No. 3, 515531 (2012).

11. M. L. Hines, A. P. Davison, and E. Muller, "NEURON and Python," Front. Neuroinform., 3, Article 1 (2009).

12. C. L. Stanfield, Principles of Human Physiology, Pearson College Division (2011).

13. G. Wilanowski and M. Piotrkiewicz, "Is spike frequency adaptation an artefact? Insight from human studies," Front. Cell. Neurosci., 6, Article 50 (2012). 
14. F. Gabbiani and H. G. Krapp, "Spike-frequency adaptation and intrinsic properties of an identified, looming-sensitive neuron," J. Neurophysiol., 96, 2951-2962 (2006).

15. B. J. Martin and H. S. Park, "Analysis of the tonic vibration reflex: influence of vibration variables on motor unit synchronization and fatigue," Eur. J. Appl. Physiol. Occup. Physiol., 75. No. 6, 504-511 (1997).

16. P. Dayan and L. F. Abbott, Theoretical Neuroscience:
Computational and Mathematical Modeling of Neural Systems. The MIT Press, London (2001).

17. W. W. Lytton, From Computer to Brain: Foundations of Computational Neuroscience, Springer, New York (2002).

18. J. R. Lieb Jr and W. N. Frost, "Realistic simulation of the Aplysia siphon-withdrawal reflex circuit: roles of circuit elements in producing motor output," J. Neurophysiol., 77. No. 3, 1249-1268 (1997). 